Vol. 13 (2004): 100-112.

\author{
Review article
}

\title{
Germination: a means to improve the functionality of oat
}

\author{
Anu Kaukovirta-Norja, Annika Wilhelmson and Kaisa Poutanen \\ VTT Biotechnology, PO Box 1500,02044VTT, Finland, e-mail: anu.kaukovirta-norja@vtt.fi
}

\begin{abstract}
The biochemical and physiological reactions of germination have long been utilised to produce barley malt for brewing and other purposes. Also some oat malt has been produced as raw-material of ale and stout production. The main goals of malting have been the degradation of grain storage components to soften the kernel structure, synthesis of amylolytic enzymes and production of nutrients for brewing yeast. Also flavour and colour attributes have been important. During the recent years interest has arisen also in the secondary metabolites produced during germination, which can have valuable health promoting properties and act as bioactive or functional compounds in foods. By using a tailored germination/malting process a desired combination of valuable properties may be obtained in germinating grains or seeds. All this requires knowledge and know-how of the germination process and the biochemistry behind it. This paper reviews the scientific knowledge about germination/malting of oat with special emphasis on changes in grain characteristics.
\end{abstract}

Key words: oat, germination, processing, bioactivity

\section{Introduction}

Germination of cereals has been used for centuries to soften kernel structure, to increase nutrient content and availability, to decrease the content of antinutritive compounds, and to add new flavours without knowing the biochemistry behind these phenomena. Barley malting is the most widely known controlled germination process, used to produce malt for brewing purposes and food applications.
Germination of a grain or seed is a chain of events that commences when viable, dry seeds imbide water, and terminates with the elongation of the embryonic axis. Upon imbibition, the quiescent seed rapidly resumes metabolic activity including respiration, enzyme and organelle activity, and RNA and protein synthesis (Bewley and Black 1994). Enzymes are synthesized to degrade storage macromolecules. These reactions lead to structural modification and development of new compounds, many of which have high bioactivity and can increase the nutritional 
value and stability of the grains. Furthermore, many of the developed compounds are flavour precursors participating in the formation of palatable malt flavour.

A traditional malting process can be divided in three main steps: steeping, germination and kilning (drying). During steeping the moisture content of the kernel is increased, normally to $43-45 \%$ to initiate germination. During germination (typically 4-7 days) enzyme synthesis and kernel modification occur under strictly controlled conditions (temperature, moisture, aeration). The aims of the kilning step (approximately 20$24 \mathrm{~h}$ ) are to dry the kernel to a moisture content of $3-5 \%$ to ensure microbiological stability of the product, to stop or retard the biochemical reactions, and to produce aroma and flavour compounds (Kunze 1999).

Oat malt is a minor product when compared to barley malt, but it is continuously produced e.g. for ale and stout brewing and for special food ingredients. Native oat is known as a health-promoting cereal with high content of soluble dietary fiber, beneficial fatty acid content and a large selection of vitamins, minerals, sterols and antioxidants. The studies of germinated/malted oat are few but cover a wide range of topics: influence of processing on the main enzyme activities, especially amylolytic, proteolytic and lipolytic activities, modification of amino acid content, fat content and composition, fiber degradation, the amount of bioactive and antinutritive compounds, and flavour formation. These topics will be discussed in more detail in the following chapters.

\section{Modification of oat macromole- cules and the development of related enzyme activities during germination}

New groups of healthy and functional foods or food ingredients have been developed during recent years including foods with slowly digestible starch, functional oligosaccharides and bioactive peptides (Crittenden and Playne 1996, Hilliam 2000, Quinquenet 2000, Peptide enriched sport drinks for enhanced recovery 2001, Company listing by category 2003). Grain storage compounds, or their degradation products could also serve as raw-materials for these novel foods or ingredients. Especially germination is a process where modified compounds and enzymes that degrade storage macromolecule are naturally formed. With the basic knowledge of hydrolysis of macromolecules, controlled utilization of amylolytic, glucanolytic and proteolytic activities of germinating grains, a range of cereal based, novel food ingredients could be achievable.

\section{Starch and other polysaccharides}

Starch is the main storage compound in oat grains constituting $60 \%$ of the dry weight (Wood et al. 1991). The starch molecules amylopectin and amylose are arranged in compound granules within the endosperm cells (Bechtel and Pomeranz 1981). During germination, starch degradation is very limited, despite the fact that starch degrading enzymes are synthesized. According to Manners and Bathgate (1969) malting of oat caused a very limited decrease in the molecular size of amylose and a small, but significant reduction in the exterior chain length of amylopectin. Sutcliffe and Baset (1973) demonstrated a close correlation between the rate of increase in amylase activity and the rate of starch degradation. The comparison of germinated oat starch to other cereal starches showed that oat starch granules were most resistant to $\alpha$-amylolysis with little increase in damaged starch and no erosion of granule surface (Lineback and Ponpipom 1977). However, release of small granules from the compound starch granules was observed. Salmenkallio-Marttila et al. (2004) found in their detailed microstructure studies that after 3 days of germination the starch granules remained intact but the protein network surrounding the 


\section{Kaukovirta-Norja, A. et al. Germination of oat}

starch granules was more dense and tightly bound than in native grains.

Hughes et al. (1997) malted different cereals by using a typical pilsner malt type malting programme and found that $\alpha$ - and $\beta$-amylase activities were much lower in oat than in barley, wheat or rye. Peterson (1998) reported that $\alpha$-amylase activity reached levels almost as high as in some barley samples but the diastatic power, characterizing the combined effects of $\beta$-amylase and $\alpha$-amylase, was much lower than in barley. Similar results were obtained already much earlier in the studies of Pomeranz and Shands (1974) who found that the levels of $\alpha$-amylase in germinated oat could be increased to the same level as in barley by addition of gibberellic acid during germination. The diastatic power, however, was lower in germinated oat than in germinated barley regardless of gibberellic acid treatment.

The main cell wall component $(2-7 \%$ of the total dry weight) in the oat endosperm is a mixed linked $(1 \rightarrow 3),(1 \rightarrow 4)$ - $\beta$-D-glucan. Oat $\beta$-glucan has a higher molecular weight than barley or rye $\beta$-glucan (Beer et al. 1997). Nutritionally, $\beta$-glucan is a dietary fiber not degraded by digestive enzymes. $\beta$-Glucan is easily extractable, forming viscous solutions and is known to decrease the levels of serum cholesterol and balance the glucose and insulin increase after meals (Ripsin et al. 1992, Welch 1995, Kahlon and Chow 1997). According to Hughes et al. (1997) $\beta$-glucanase activity of oat was comparable to that of wheat but much lower than that of barley and rye. Despite this considerably low $\beta$-glucanase activity, the $\beta$-glucan content decreased significantly during malting from $3.5 \%$ to $0.6 \%$. Peterson (1998) also found that $\beta$-glucans were almost totally degraded during a 6-day germination. However, the content and properties of $\beta$ glucans are important also in malted oat products if the cholesterol lowering and other functional effects of fiber are to be maintained. Especially, the ability of oat products to develop highly viscous matrices is known to depend on the molecular weight and viscosity of $\beta$-glucans, and furthermore, this ability is known to be influenced by processing (Beer et al. 1997, Zhang et al. 1998, Gallaher et al. 1999). Therefore, Wilhelmson et al. (2001) developed a short malting process for oat aiming to retain high $\beta$-glucan content also in malted oat. Up to $70 \%$ of the $\beta$-glucans could be restored, and the average molecular weights $\left(M_{w}\right.$ and $\left.M_{n}\right)$ of $\beta$-glucan molecules changed only slightly during malting. The major changes in $\beta$-glucan reserves during this short malting were observed in the crushed cell layer beneath the scutellum (SalmenkallioMarttila et al. 2004).

\section{Amino acid composition and protein degrading enzymes}

Oat contains 15-20\% proteins (Robbins et al. 1971, McMullen 1991). The nutritional value of oat proteins is higher than that of other cereal proteins due to lower content of prolamine protein (Peterson 1976, Hamad and Fields 1979). The total protein content of oat increases slightly during germination due to more intensive degradation of other kernel components for respiration (Dalby and Tsai 1976). Dalby and Tsai (1976) and Wu (1983) observed an increase in albumin content (rich in essential amino acids, lysine and tryptophane) during oat germination, and a subsequent decrease in globulin and prolamine contents (poor in lysine) leading to increased nutritional value of germinated oat. Hamad and Fields (1979) also found an increase in lysine content during germination, but the calculations did not show any significant increase in the nutritional value of oat when compared to casein. Shutov and Vaintraub (1987) have proposed that globulins undergo changes in their solubility at the beginning of germination, making them more susceptible for seed endoproteinases. These endoproteinases are also synthesized at the beginning of germination.

Sutcliffe and Baset (1973) showed an increase in casein hydrolysing activity in oat during germination. The rate of activity increased during the first two days of germination. The results of Mikola and Jones (2000a) showed that a wide range of oat endoproteinases were able 
to hydrolyse the insoluble oat storage proteins. The serine and metalloproteinases hydrolysed oat proteins in dissolved form, and when oat proteins were in a bound form cysteine endoproteinase was the main degrading activity. Mikola and Jones (2000b) and Mikola et al. (2001) studied the hydrolysis on oat globulins and oat avenins in detail. In the beginning of germination, oat globulins were hydrolysed into intermediate molecular weight peptides. These peptides did not accumulate in the grain but they disappeared at the same rate as intact globulins (Mikola and Jones 2000b). Cysteine proteinases are assumed to be responsible for the initiation of oat globulin hydrolysis. The degradation of oat prolamins, avenins, started in the beginning of germination with hydrolysis of $\alpha$-avenins followed with hydrolysis of $\beta$-avenins after an 8-day germination (Mikola et al. 2001). Additionally, cysteine proteinases are regarded responsible for the initiation of avenin hydrolysis.

\section{Lipids and lipid degradation}

Oat contains more lipids than other cereals, normally 5-9\% (Sahasrabudhe 1979, Youngs 1986, Saastamoinen et al. 1989). In oat, lipids are located throughout the kernel, while lipids in other cereals are concentrated in the embryo (Lockhart and Hurt 1986). Most of the oat fatty acids are unsaturated. The oleic acid portion of oat lipids is exceptionally high among cereal lipids (Youngs 1986, Saastamoinen et al. 1989). Furthermore, oat is exceptional among cereals in that it contains a significant lipid hydrolysing (lipase) activity already in native, quiescent grains (Urquhart et al. 1983, 1984, Liukkonen et al. 1993, Ekstrand et al. 1993). Still, lipids of dry, intact oat grains can stay stable for years when stored at proper conditions (Welch 1977). On the other hand, Ekstrand et al. (1993) reported a marked increase in free fatty acids during storage of whole grains already after 16 weeks at $30^{\circ} \mathrm{C}$ indicating the susceptibility of oat lipids to hydrolysis. Lehtinen et al. 2002 observed that routinely applied heat treatment used to inactivate oat lipase was insufficient to increase the storage stability of oat products and instead, could even accelerate the oxidative deterioration of oat lipids. All together, even though native oat contains less oxidative lipoxygenase enzyme than many other grains, like barley, wheat or maize (von Ceumern and Hartfield 1984), the stability of oat lipids and the preventation of off-flavour formation are great challenges to the oat processing industry due to the high lipid content, high native lipolytic activity of oat and, according to Lehtinen et al. (2002) the susceptability of some oat lipid fractions to normally used heat treatments.

Urquhart et al. (1983) did not observe any marked increase in oat lipase activity during a 4-day germination. However, the location of lipase partly changed during germination from the bran-endosperm fraction to the embryo. Ekstrand et al. (1992) noticed an increase in lipase activity at neutral and alkaline $\mathrm{pH}$ while the activity at acidic $\mathrm{pH}$ remained relatively constant. They suggested that the lipase activity in alkaline $\mathrm{pH}$ was related to the metabolic processes of the embryo during germination. Peterson (1998) studied the degradation of lipids during malting in 39 hull-less oat varieties (46 samples) and in 10 hulled varieties. The hull seemed to have influence on lipid reactions during germination. The total lipid content of hull-less varieties was higher than in hulled varieties, $5.7-10.2 \%$ and $4.4-9.6 \%$, respectively. The proportion of free fatty acids in native, hull-less samples was higher than in hulled samples. During germination, the decrease in the total lipid content of hull-less samples was $15 \%$ on average and in hulled samples approximately $5 \%$. In fact, in half of the hulled samples, the total lipid content increased during malting. On the other hand, the formation of free fatty acids during germination was more intense in hulled samples than in hull-less ones indicating the occurrence of both formation and degradation of lipids during germination.

Peterson (1999) studied further the relationship between lipase activity and the lipid metabolism during germination. He found that the 


\section{Kaukovirta-Norja, A. et al. Germination of oat}

concentration of free fatty acids increased remarkably during a 6-day malting, but the total lipase activity decreased $40 \%$. He concluded that there was no correlation between total lipase activity and the degradation of triglycerides and suggested the occurrence of oil body bound lipase which is responsible for the degradation of storage lipids.

Outinen (1999) studied the influence of malting conditions on the lipid content and lipolytic activity on one hulled (originally high in lipolytic activity) and on one hull-less (originally moderate lipolytic activity) variety, and reported quite different results from those of Peterson (1998). In general, no lipid degradation or significant formation of free fatty acids was seen during germination. On the contrary, in most of the malted samples the lipid content increased. Lipolytic activity of hulled oat with high original activity remained stable or decreased a little in all used malting conditions. On the other hand, in the hull-less sample with moderate original lipolytic activity this activity was further increased under some malting conditions. No increase in lipid oxidising activity during malting of oat was observed in studies of Outinen (1999). It can be concluded that the research results on lipolysis in oat germination are to some extent contradictionary and further research is needed in this area.

\section{Bioactive compounds of germinated oat}

In addition to macrocomponents of which especially $\beta$-glucan has interesting positive health effects, oat contains microcomponents of which many are also physiologically active. Phytates are $\mathrm{Ca}-, \mathrm{K}$ - and $\mathrm{Mg}$-salts of myo-inositolhexaphosphate, which serves as a phosphate reserve in the kernel (Hall and Hodges 1966, Fredlund et al. 1997, greiner and Alminger 1999). Furthermore, oat contains various interesting bioactive compounds that are products of secondary metabolism. These compounds include vitamins, sterols and phenolic compounds. They can affect the nutritional and functional properties and stability of oat products. By germination, the concentration and availability of these compounds can be adjusted.

\section{Phytate content and phytase activity}

Phytates are negatively charged molecules and can form complexes or otherwise bind metal ions and proteins, and thereby influence the absorption of trace elements and activity of proteins in the gastrointestinal tract (Zhou and Erdman 1995). Phytic acid can also prevent absorption of calcium (Sandberg et al. 1993, Saha et al. 1994). Even though oat has a high mineral content, the absorption of iron and zinc from a breakfast containing oat porridge is low (Sandström et al. 1987, Rossander-Hultén et al. 1990). In a multifunctional diet, which contains high amounts of mineral substances, the influence of phytate is insignificant. However, in diets rich in cereal based foods, the influence of phytate on mineral balance can be remarkable. This can be the case with vegetarians and people of the third world (Larsson et al. 1996). On the other hand, phytic acid has also been reported to have health promoting effects. Phytic acid and its degradation products are believed to contribute to prevention of colon cancer and cardiovascular diseases (Graf and Eaton 1993, Shamsuddin 1995).

Oat phytate is known to be difficult to degrade (Larsson and Sandberg 1992, Marklinder et al. 1995). Fretzdorff (1992) noticed that the degradation of phytate during germination was significantly lower in oat than in other cereals. On the other hand, Marklinder et al. (1995) reported that malted barley flour and malted oat flour had the same capacity to degrade oat phytate. The phytate content could be further decreased when malted oat or malted oat flour was incubated in water, indicating an increase in phytase activity during germination (Fretz- 
dorff 1992, Larsson and Sandberg 1992). The optimal condition for incubation was $17 \mathrm{~h}$ at $37-$ $40^{\circ} \mathrm{C}$ (Larsson and Sandberg 1992, 1995). The results from germination studies were reflected in the clinical data: Larsson et al. (1996) reported that the use of malted oat in preparation of breakfast porridge significantly increased the uptake of iron and zinc in human subjects. According to Oksman-Caldentey et al. (2001) the phytate content could be decreased 15-35\% during even a short 3 day germination process.

Rather recently oat phytase was isolated and purified for the first time (Greiner and LarssonAlminger 1999). The enzyme is a $67 \mathrm{kDA}$ monomeric protein with $\mathrm{pH}$ optimum at 5.0 and it is strongly inhibited by phosphatate resulting from phytate degradation. Greiner and Larsson-Alminger (1999) suggested that inhibition will not occur in a growing plant since the seedling can probably remove the released phosphate actively or passively.

\section{Sterols}

Sterols are minor lipids with significant biological functions. White and Armstrong (1986) reported an improved stability of soybean oil after addition of purified oat sterols. In plants sterols are present as free sterol alcohols, steryl esters and steryl glycosides (Dyas and Goad 1993). The major sterol compound in oat is $\beta$-sitosterol (Lásztity 1998, Määttä et al. 1999). OksmanCaldentey et al. (2001) measured up to $20 \%$ increase in sterols during germination of oat. Sitostanol was found to be synthesized during germination. Oat sterols were shown to be heat-stable when germinated oat was dried at different temperatures.

\section{Vitamins}

Oat contains mainly lipid soluble tocols (vitamin E) and water soluble vitamin B. The main tocols in oat are $\alpha$-tocopherols and $\alpha$-tocotrienols (Hammond 1983). Oat and oat products contain high amounts of thiamin and pantothenic acid (Lockhart and Hurt 1986) and are especially rich in biotin compared to other cereals (Lásztity 1998). Germination has been used to produce a vitamin-rich oat drink (DE 3741991). Oksman-Caldentey et al. (2001) reported a 20\% increase in the content of several oat B vitamins like biotin, niacin, pantothenic acid and B6 vitamin during germination.

\section{Phenolic compounds}

Phenolic compounds act as a part of the defence mechanisms of plants, protecting plants against pathogens, pests and other stress conditions (drought, UV-light, etc). In general, they have antimicrobial, antioxidative and anti-carcinogenic properties (Pratt 1992). Oat contains quinones of benzoic acid cinnamic acids, flavones, flavonols, flavanones, anthocyanidins, aminophenols and precursors of these compounds (Collins 1986). Totally native oat flour contains $87 \mathrm{mg} / \mathrm{kg}$ fenolic acids, the main component being ferulic acid (Sosulski et al. 1982). OksmanCaldentey et al. (2001) reported that the total phenolic content of oat increased 3- to 4-fold during a short germination process. This could also reflect to the better extractability of phenolic compounds from kernel structures after germination. After germination most of the phenolics were bound $(58 \%)$, in ester form $(25 \%)$, or in glucosidic form (15\%). Only $2-3 \%$ of phenolic acids were free. The major free acids were caffeic acid, syringic acid, ferulic acid and sinapic acid.

Avenanthramides are special oat phenolics, which are regarded as central compounds of the defence mechanism (Collins 1989, Dimberg et al. 1993). The avenantramides occur as constitutive components of oat grains. In oat leaves, avenanthramides are not detected until the leaves are inoculated with an incompatible race of the oat crown rust pathogen, Puccinia coronata $\mathrm{f}$. sp. avenae (Miyagawa et al. 1995) or other fungal elicitor, such as victorin (Miyagawa et al. 1996). Germination increased the amount of avenanthramides significantly (Kaukovirta-Norja et 


\section{Kaukovirta-Norja, A. et al. Germination of oat}

al. 2001, Oksman-Caldentey et al. 2001). An especially high increase in avenanthramide content was observed in a hull-less variety (up to 35 -fold increase) indicating the special role of avenanthramides in plant protection. Bryngelsson et al. (2003) also observed a significant increase in concentration of avenantramides during steeping and germination of oat.

Phenolic compounds are known to be bitter tasting and therefore may not be advantageous for cereal products. However, different phenolics have different flavour characteristics. According to Dimberg et al. (1996) and Molteberg et al. (1996) avenanthramides and caffeic acid were significantly correlated with low rancidity, a lack of bitterness, and freshness, whereas the opposite was found for most of the simple phenolic compounds.

Phytoestrogens are one interesting group of plant phenolic compounds with reported antitumoral (Adlercreutz et al. 1995) and antioxidative activities (Fleury et al. 1992). However, germination has not been shown to influence oat phytoestrogens, e.g. lignan content or composition (Oksman-Caldentey et al. 2001).

\section{Total antioxidant activity}

Special antioxidative properties of oat have been known for a long time. The antioxidants are concentrated mainly in the outer layers of the oat kernel (Peterson 2001). Phenolic compounds and tocols are mainly regarded responsible for oat antioxidant activity (Hammond 1983, Forssell et al. 1990). Oat sterols have also been reported to have antioxidative properties (White and Armstrong 1986, Kahlon 1989). Forssell et al. (1992) reported that oat lecithin is a better antioxidant than soy or turnip rape lecithin. Emmons et al. (1999) found that the total phenolic content of oat was significantly correlated with antioxidant activity, measured by $\beta$-carotene bleaching. Also other methods measuring total antioxidant activity gave similar results.

The total antioxidativity of oat, measured as DPPH (diphenylpicrylhydratcyl) radical scav- enging activity, increased during germination (Kaukovirta-Norja et al. 2001, Oksman-Caldentey et al. 2001). The total phenolic content of germinated oat correlated well with total antioxidativity, indicating that a significant part of the increased antioxidativity was due to phenolic compounds. The antioxidativity was significantly higher in the hull-less oat variety than in the hulled variety (Oksman-Caldentey et al. 2001).

\section{Influence of germination on oat flavour}

Oat is perceived as a tasty cereal with palatable, nutty-like flavour (Heydanek and McGorrin 1986). Oat flavour is mainly formed during processing. The germination process is well known to intensify both colour and flavour of grain products. The kilning (drying) step of a germination/malting process is especially important in the formation of different kind of flavours in germinated grains. The Maillard reaction is one of the major reactions influencing the flavour and colour of a germinated, dried products (Fayle and Gerrard 2002). For germinated oat, the most salient sensory attributes were roasted odour and flavour, sweet taste, intense odour, intense aftertaste and hard, crisp, brittle texture (Heiniö et al. 2001). Relatively high drying temperatures $\left(>85^{\circ} \mathrm{C}\right)$ were necessary to produce these sensory attributes. Sensory and instrumental profile analyses of selected volatile compounds showed that roasted, sweet and nutty attributes were related to dimethyl sulphides and isobutanol. Furthermore, phenolic compounds seemed to influence oat flavour significantly. Although free fatty acids are generally supposed to affect the sensory quality, they had a negligible effect in the study of Heiniö et al. (2001). 


\section{Microbiological quality and shelf- life of germinated oat}

When oat germination or malting are used to produce novel food ingredients, a controlled process and the stability and shelf-life of the products are essential. Microbial aspects have to be taken into account in wet grain processing.

\section{Microbiological quality of germinated oat}

The microbial flora characteristic of oat and oat products develops in the field before harvest, under storage, and during oat processing. Moulds, normally divided into field and storage fungi, are typical spoilage microbes of cereals. Especially Aspergillus and Penicillium storage fungi are known to be responsible for the deterioration of dry oat products like flakes and muesli (Weidenbörner and Kunz 1994, 1995, Nogueira and Cavalcanti 1996, Nogueira et al. 1996). Toxin forming Fusarium species are typical field fungi of oat products. According to Hietaniemi and Kumpulainen (1991, 1993), oat seemed to be more susceptible to Fusarium mycotoxins than rye, wheat or barley. However, Fusarium toxin formation is greatly dependent on the Fusarium species and climate conditions (Gareis et al. 1989).

Germination conditions favour microbial growth. Changes in the composition of microflora during barley malting and the effects of microbes on malt and beer quality have been studied extensively (Petters et al. 1988, Flannigan 1996, Noots et al. 1998). It is well known that microbes in and on the outer layers of kernels greatly influence the quality of the final product. Aerobic microbes compete with grain tissue for dissolved oxygen during the steeping of the kernels, and uncontrolled multiplication of microbes may lead to poor germination (Doran and Briggs 1993). Wilhelmson et al. (2001) studied the changes in microflora during germination of hulled and hull-less oat varieties at dif- ferent germination temperatures. Results showed clearly that elevated germination temperatures led to an increase in Fusarium, aerobic heterotrophic bacteria, Pseudomonas spp., lactic acid bacteria, and aerobic spore-forming bacteria. The hull-less variety was more susceptible to Fusarium contamination at high temperatures. However, at moderate $15^{\circ} \mathrm{C}$ temperature only one oat sample contained low amounts of the Fusarium toxin deoxynivalenol indicating the importance of germination temperature for control of microflora and toxin formation. Bacillus cereus or Clostridium species were not detected in any of the samples. This was beneficial because heatresistant spores of Bacillus species cause spoilage of bread by rope formation and may also constitute a health risk (Kramer and Gilbert 1989, Thomson et al. 1993).

Oksman-Caldentey et al. (2001) used lactic acid starter cultures to control microflora during germination. The use of starter cultures significantly decreased the total bacterial content and content of Pseudomonas spp. of malted oat. Furthermore, starter cultures inhibited the growth of Fusarium spp. during oat germination.

\section{Stability of oat lipids after germination}

The germination process itself does not, in general, deteriorate oat lipids. However, during germination the amount of reducing sugars increases, resulting in perceived sweetness, and the amount of free fatty acids may rise, increasing the risk of rancidity (Peterson 1998). Heiniö et al. (2002) studied the influence of germination on lipid and flavour stability of oat products (oat groats). A possible relationship between a decrease in lipolytic activity during oat germination (Outinen 1999, Heiniö et al. 2001) on storage stability was investigated. In accordance with the lower lipolytic activity of germinated oat, the accumulation of free fatty acids was slower in germinated oat when compared to native oat during the first two months of storage (Heiniö et al. 2002). After that, the formation of free fatty acids was similar or faster in germinated oat than 
Kaukovirta-Norja, A. et al. Germination of oat

in native oat. However, the degree of unsaturation characterizing oxidation of lipids did not change in germinated oat samples but was clearly reduced in native oat samples. Furthermore, the concentration of volatile aldehydes and ketones regarded as secondary oxidation products of unsaturated fatty acids was lower in germinated oat samples during the whole 12 month storage period when compared to native oat samples. The formation of volatile compounds related to lipid oxidation was closely correlated with the development of the undesired sensory attributes. Therefore, the sensory stability of germinated oat groats was better than that of oat groats made from native oat.

\section{Utilization of germinated oats}

Germination process can be regarded as a pretreatment of cereal raw material with aims to modify the structure and composition of kernel for further processing. The changes in structure may influence the processability of kernels e.g. in fractionation or extraction processes, and furthermore, influence the absorption of nutrients or the bioavailability of functional components in humans and aminals. In addition, the softer kernel structure of germinated oat opens new possibilities to use whole kernels in human and animal nutrition.

Oat malt is commercially available from several companies. So far, it has been mainly used in breweries as a minor raw-material in ale and stout production to tune beer flavor. A recent study (Taylor et al. 1998) showed that malted oat provided a pronounced toasted, biscuity aroma and palate, combined with a creamy and relatively intense mouthfeel in beer. These flavour effects were apparent at less that $10 \%$ replacement of barley malt with malted oat.

Some other application have also been developed for malted oat in bakery, biscuit, cereal bar and confectionary industries (Oat cuisine 1989). Also the production of a vitamin-rich oat drink (DE 3741991) and snack foods (PCT/FI01/ 00865) based on malted oat has been suggested. However, only a minor part of the great potential of germinated/malted oat has currently been utilised. Bread and bisquits as well as breakfast cereals are natural end-products for the use of oat malt. Textural and flavour changes induced during germination and finalised in the subsequent heat treatments could also be the basis of new product concepts, providing the modern consumer with healthy, whole grain foods in a palatable form.

As the present review shows, the basic biochemical reactions in oat kernel during germination are quite well known and documented. The tools to develop tailored germination processes and to create novel, functional oat compounds and fractions are therefore available. The main challenges for the development of new ingredients and products from germinated oat is to find the innovative ways to combine different prosessing methods i.e. drying, fractionation, extraction, extrusion with germination and to formulate the final product concepts that attract consumers of different origin. In addition, the stability and sufficient shelf-life are important success criteria of all oat products and should therefore always be addressed.

\section{References}

Adlercreutz, C.H.T., Goldin, B.R., Gorbach, S.L., Höckerstedt, K.A.V., Watanabe, S., Hämäläinen, E.K., Markkanen, M.H., Mäkelä, T.H., Wähälä, K.T., Hase, T.A. \& Fotsis, T. 1995. Soybean phytoestrogen intake and cancer risk. Journal of Nutrition 125: 757-770.

Bechtel, D.B. \& Pomeranz, Y. 1981. Ultrastructure and cytochemistry of mature oat (Avena sativa L.) endosperm. The aleurone layer and starchy endosperm. Cereal Chemistry 58: 61-69.

Beer, M.U., Wood, P.J. \& Weisz, J. 1997. Molecular weight distribution and $(1 \rightarrow 3)(1 \rightarrow 4)-\beta-D$-glucan content of consecutive extracts of various oat and barley cultivars. Cereal Chemistry 74: 476-480.

Bewley, J.D. \& Black, M. 1994. Seeds: physiology of development and germination. Plenum Press, NY. 445 p.

Bryngelsson, S., Ishihara, A., \& Dimberg, L.H. 2003. Levels of avenanthramides and activity of hydroxycin- 
Vol. 13 (2004): 100-112.

namoyl-CoA:hydroxyanthranilate $\mathrm{N}$-hydroxycinnamoyl transferase (HHT) in steeped or germinated oat samples. Cereal Chemistry 80: 356-360.

Collins, F.W. 1986. Oat phenolics: structure, occurrence and function. In: Webster, F.H. (ed.). Oats: chemistry and technology. American Association of Cereal Chemists, St. Paul, Minnesota, p. 227-295.

Collins, F.W. 1989. Oat phenolics: avenanthramides, novel substituted $\mathrm{N}$-cinnamoyl-anthranilate alkaloids from oat groats and hulls. Journal of the Agricultural and Food Chemistry 37: 60-66.

Company listing by category 2003. Functional Foods \& Nutraceuticals October. p. 22-38.

Crittenden, R.G. \& Playne, M.J. 1996. Production, properties and applications of food-grade oligosaccharides. Trends in Food Science \& Technology 7: 353-361.

Dalby, A. \& Tsai, C.Y. 1976. Lysine and tryptophan increases during germination of cereal grains. Cereal Chemistry 53: 222-226.

DE 3741991. Göbel, A. \& Hitze, W. Trinkbarer wasserhaltiger Ekstrakt mit einem Gehalt an Wirk- und Werkstoffen des gekeimten Getreides und/oder von Leguminosen und/oder sonstiger körnerartiger Samen. Patent. 1987.

Dimberg, L., Theander, O. \& Lingnert, H. 1993. Avenanthramides - A group of phenolic antioxidants in oats. Cereal Chemistry 70: 637-641.

Dimberg, L.H., Molteberg, E.L., Solheim, R. \& Frølich, W. 1996. Variation in oat groats due to variety, storage and heat treatment. I: Phenolic compounds. Journal of Cereal Science 24: 262-272.

Doran, P.J. \& Briggs, D.E. 1993. Microbes and grain germination. Journal of the Institute of Brewing 99: 165170.

Dyas, L. \& Goad, L.J. 1993. Steryl fatty acid esters in plants. Phytochemistry 34: 17-29.

Ekstrand, B., Gangby, I. \& Åkesson, G. 1992. Lipase activity in oats - distribution, $\mathrm{pH}$ dependence and heat inactivation. Cereal Chemistry 69: 379-381.

Ekstrand, B., Gangby, I., Åkesson, G., Stöllman, U., Lignert, H. \& Dahl, S. 1993. Lipase activity and development of rancidity in oat and oat products related to heat treatment during processing. Journal of Cereal Science 17: 247-254.

Emmons, C.L., Peterson, D.M. \& Paul, G.L. 1999. Antioxidant capacity of oat (Avena sativa L.) extracts. 2. In vitro antioxidant activity and contents of phenolic and tocol antioxidants. Journal of Agricultural and Food Chemistry 47: 4894-4898.

Fayle, S.E. \& Gerrard, J.A. 2002. The Maillard reaction. The Royal Society of Chemistry, Cambridge, UK. $120 \mathrm{p}$.

Flannigan, B. 1996. The microflora of barley and malt. In: Priest, F.G. \& Campell, I. (eds.). Brewing microbiology. 2nd ed. Chapman \& Hall, London. p. 83-125.

Fleury, Y., Welti, D.H. \& Philippossian, G. 1992. Soybean (Malonyl) isoflavones characterization and antioxidant properties. In: Huang, M.T. et al. (eds.). Phenolic compounds in food and their effects on health. II Antioxidants and cancer preventation. ACS Symposium Series 507, American Chemistry Society, Washington DC. p. 98-113.
Forssell, P., Cetin, M., Wirtanen, G. \& Mälkki, Y. 1990. Antioxidative effects of oat oil and its fractions. Fat Science and Technology 8: 319-321.

Forssell, P., Kervinen, R., Alkio, M. \& Poutanen, K. 1992. Comparison of methods for separating polar lipids from oat oil. Fat Science and Technology 9: 355358.

Fredlund, K., Asp, N.-G., Larsson, M., Marklinder, I. \& Sandberg, A.-S. 1997. Phytate reduction in whole grains of wheat, rye, barley and oats after hydrothermal treatment. Journal of Cereal Science 25: 83-91.

Fretzdorff, B. 1992. Phytinsäure in Getreidennährmitteln - Bestandsaufnahme und Möglichkeiten der reduction. Getreide, Mehl and Brot 46: 180-185.

Gallaher, D.G., Wood, K.J., Gallaher, C.M., Marquardt, L.F. \& Engström, A.M. 1999. Intestinal contents supernatant viscosity of rats fed oat-based muffins and cereal products. Cereal Chemistry 76: 21-24.

Gareis, M., Bauer, J., Enders, C. \& Gedek, B. 1989. Contamination of cereals and feed with Fusarium mycotoxins in European countries. In: Chelkowski, J. (ed.). Cereal grain: mycotoxins, fungi and quality in drying and storage. Elsevier, Amsterdam. p. 441-472.

Graf, E. \& Eaton, J.W. 1993. Suppression of colonic cancer by dietary phytic acid. Nutrition and Cancer 19: 11-19.

Greiner, R. \& Larsson-Alminger, M. 1999. Purification and characterization of a phytate-degrading enzyme from germinated oat (Avena sativa). Journal of the Science of Food and Agriculture 79: 1453-1460.

Hamad, A.M. \& Fields, M.L. 1979. Evaluation of the potential and available lysine of germinated and fermented cereals. Journal of Food Science 44: 456459.

Hammond, E.G. 1983. Oat lipids. In: Barnes, P.J. (ed.). Lipids in cereal technology. Academic Press Inc. London. p. 331-352.

Hall, J.R. \& Hodges, T.K. 1966. Phosphorus metabolism of germinating oat seeds. Plant Physiology 41:14591464.

Heiniö, R.L., Lehtinen, P., Oksman-Caldentey, K.-M. \& Poutanen, K. 2002. Differences between sensory profiles and development of rancidity during long-term storage of native and processed oat. Cereal Chemistry 79: 367-375.

Heiniö, R.L., Oksman-Caldentey, K.-M., Latva-Kala, K., Lehtinen, P. \& Poutanen, K. 2001. Effect of drying treatment conditions on sensory profile of germinated oat. Cereal Chemistry 78: 707-714.

Heydanek, M.G. \& McGorrin, R.J. 1986. Oat flavour chemistry: principles and prospects. In: Webster, F.H. (ed.). Oats: chemistry and technology. American Association of Cereal Chemists, Inc. St Paul: MN USA. p. 335-369.

Hietaniemi, V. \& Kumpulainen, J. 1991. Contents of Fusarium toxins in Finnish and imported grains and feeds. Food Additive Contaminants 8: 171-182.

Hietaniemi, V. \& Kumpulainen, J. 1993. Mycotoxins in cereal grains and feeds in Finland. In: Aalto-Kaarlehto, T. \& Salovaara, H. (eds.). Proceedings from the 25th Nordic cereal congress, Helsinki, June 6-9. EKT Series 930. p. 54-59. 


\title{
AGRICULTURAL AND FOOD SCIENCE
}

\author{
Kaukovirta-Norja, A. et al. Germination of oat
}

Hilliam, M. 2000. Global functional foods industry looks forwards. The World of Food Ingredients. January. p. 40-43.

Hughes, G.P., Hyde, M., Woll, S. \& Gill, W.G. 1997. Malting potential and associated physiological characteristics of naked barley, rye, rice, oats and wheat. In: Proceedings of the 8th Australian barley technical symposium, Queensland, Australia. p. 2: 4.12-15.

Kahlon, T.S. 1989. Nutritional implications and uses of wheat and oat kernel oil. Cereal Foods World 34:872875.

Kahlon, T.S. \& Chow, F.I. 1997. Hypercholesterolic effects of oat, rice and barley dietary fibers anf fractions. Cereal Foods World 42: 86-92.

Kaukovirta-Norja, A., Oksman-Caldentey, K.-M., Heiniö, R.-L., Lehtinen, P., Pihlava, J.-M. \& Poutanen, P. 2001. Germination increased bioactivity and stability of whole grain oats. In: Liukkonen, K. et al. (eds.). International symposium on whole grain and human health, Haikko Manor, June 13-15. VTT Symposium 213. p. 96.

Kramer, J.M. \& Gilbert, R.J. 1989. Bacillus cereus and other Bacillus species. In: Doyle, M.P. (ed.). Foodborne bacterial pathogens. Marcel Dekker, Inc., New York. p. 22-70.

Kunze, W. 1999. Malt production. In: Technology Brewing and Malting. VLB Berlin. p. 88-170.

Larsson, M., Rossander-Hultén, L., Sandström, B. \& Sandberg, A.-S. 1996. Improved zinc and iron absorption from breakfast meals containing malted oats with reduced phytate content. British Journal of Nutrition 76: 677-688.

Larsson, M. \& Sandberg, A.-S. 1992. Phytate reduction in oats during malting. Journal of Food Science 57: 994-997.

Larsson, M. \& Sandberg, A.-S. 1995. Malting of oats in a pilot-plant process. Effects of heat treatment, storage, and soaking conditions on phytate reduction. Journal of Cereal Science 21: 87-95.

Lásztity, R. 1998. Oat grain - a wonderful reservoir of natural nutrients and biologically active substances. Food Review International 14: 99-119.

Lehtinen, P., Kiiliainen, K., Lehtomäki, I. \& Laakso, S. 2002. Effect of heat treatment on lipid stability in processed oats. Journal of Cereal Science 37: 215-221.

Lineback, D.R. \& Ponpipom, S. 1977. Effects of germination of wheat, oats and pearl millet on $\alpha$-amylase activity and starch degradation. Staerke 29: 52-60.

Liukkonen, K., Kaukovirta-Norja, A. \& Laakso, S. 1993. Elimination of lipid hydrolysis in aqueous suspensions of oat flour. Journal of Cereal Science 17: 255-165.

Lockhart, H.B. \& Hurt, H.D. 1986. Nutrition of oats. In: Webster, F.H. (eds.). Oats: chemistry and technology. American Association of Cereal Chemists, St. Paul, Minnesota. p. 297-308.

Määttä, K., Lampi, A.-M., Petterson, J., Fogelfors, B.M., Piironen, V. \& Kamal-Eldin, A. 1999. Phytosterol content in seven oat cultivars grown at three locations in Sweden. Journal of the Science of Food and Agriculture 79: 1021-1027.

Manners, D.J. \& Bathgate, G.H. 1969. $\alpha$-1,4-Glucans. Part $\mathrm{XX}$. The molecular structure of the starches from oats and malted oats. Journal of the Institute of Brewing 75: 169-175.

Marklinder, I.M., Larsson, M., Fredlund, K. \& Sandberg, A.-S. 1995. Degradation of phytate by using varied sources of phytases in an oat-based nutrient solution fermented by Lactobacillus plantarum strain 299 V. Food Microbiology 12: 487-495.

McMullen, M.S. 1991. Oats. In: Lorenz, K.J. \& Kulp, K. (eds.). Handbook of cereal science and technology. Marcel Dekker, Inc., New York. p. 199-232.

Mikola, M., Brinck, O. \& Jones, B.L. 2001. Characterization of oat endoproteinases that hydrolyze oat avenins. Cereal Chemistry 78: 55-58.

Mikola, M. \& Jones, B.L. 2000a. Electrophoretic and 'in solution' analyses of endoproteinases extracted from germinated oats. Journal of Cereal Science 31: 1523.

Mikola, M. \& Jones, B.L. 2000b. Characterization of oat endoproteinases that hydrolyze oat globulins. Cereal Chemistry 77: 572-577.

Miyagawa, H., Ishihara, A., Kuwahara, Y., Ueno, T. \& Mayama, S. 1996. A stress compound in oats induced by victorin, a host-specific toxin from Helminthosporium victoriae. Phytochemistry 41: 1473-1475.

Miyagawa, H., Ishihara, A., Nishimoto, T., Ueno, T. \& Mayama, S. 1995. Induction of avenanthramides in oat leaves inoculated with crown rust fungus, Puccinia coronata f. sp. avenae. Bioscience, Biotechnology and Biochemistry 59: 2305-2306.

Molteberg, E.L., Solheim, R., Dimberg, L.H. \& Frølich, W. 1996. Variation in oat groats due to variety, storage and heat treatment. II: Sensory quality. Journal of Cereal Science 24: 273-282.

Nogueira, E.B., da S. \& Cavalcanti, M.A. de Q. 1996. Cellulolytic fungi isolated from processed oats. Revista de Microbiologia 27: 7-9.

Nogueira, E.B., da S., Cavalcanti, M.A. de Q.\& Fernandes, M.J. dos S. 1996. Mesophilic and thermophilic filamentous fungi isolated from processed oats (Avena sativa L) in Brazil. Boletin Micologico 11: 63-67.

Noots, I., Delcour, J.A. \& Michiels, C.W. 1998. From field barley to malt: detection and specification of microbial activity for quality aspects. Critical Reviews in Microbiology 25: 121-153.

Oat cuisine 1989. Confectionery, Manufacture and Marketing 26: 32, 34.

Oksman-Caldentey, K.-M., Kaukovirta-Norja, A., Heiniö, R.-L., Kleemola, T., Mikola, M., Sontag-Strom, T., Lehtinen, P., Pihlava, J.-M. \& Poutanen, P. 2001. Kauran biotekninen prosessointi uusiksi elintarvikkeiksi. (Biotechical processing of oat for novel food ingredients). In: Salovaara, H. \& Sontag-Strom, T. (eds.). Kaurasta elinvoimaa. EKT-sarja 1221. Helsingin yliopisto, Elintarviketeknologian laitos. p. 85-108. (in Finnish.)

Outinen, M. 1999. Mallastuksen vaikutus kauran lipideihin (Influence of germination on oat lipids). M.Sc. Thesis, Helsinki University of Technology, Espoo, Finland. $94 \mathrm{p}$.

Peptide enriched sport drinks for enhanced recovery 2001. Innovations in Food Technology February/ March. p. 18-20. 
Vol. 13 (2004): 100-112.

PCT/FI01/00865. Myllymäki, O., Poutanen, K., OksmanCaldentey, K.-M., Laitila, A. and Heiniö, R.-L. Method for producing an oat product and an oat cereal and a snack product produced with said method (Menetelmä kauratuotteen valmistamiseksi ja menetelmällä valmistettu kauramuro ja välipalatuote). International patent application 2000.

Peterson, D.M. 1976. Protein concentration, concentration of protein fractions and amino acid balance in oats. Crop Science 16: 663-666.

Peterson, D.M. 1998. Malting oats: Effects on chemical composition of hulled and hull-less genotypes. Cereal Chemistry 75: 230-234.

Peterson, D.M. 1999. Lipase activity and lipid metabolism during oat malting. Cereal Chemistry 76: 159163.

Peterson, D.M. 2001. Oat antioxidants. Journal of Cereal Science 33: 115-129.

Petters, H.I., Flannigan, B. \& Austin, B. 1988. Quantitative and qualitative studies of the microflora of barley malt production. Journal of Applied Bacteriology 65: 279-297.

Pomeranz, Y. \& Shands, H.L. 1974. Gibberellic acid in malting of oats. Journal of Food Science 39: 950952.

Pratt, D.E. 1992. Natural antioxidants from plant material. In: Huang, M.T. et al. (eds.). Phenolic compounds in food and their effects on health. II Antioxidants and cancer preventation. ACS Symposium Series 507. American Chemistry Society, Washington DC. p. 54.

Quinquenet, S. 2000. Actilight ${ }^{\circledR}$ short-chain fructo-oligosaccharides: the first soluble fibres which promote Bifidus flora. Agro-Food Industry Hi-Tech 11: 18-19.

Ripsin, C.M., Keenan, J.M., Jacobes, D.R., Elmer, P.J., van Horn, L., Liu, K., Turnbull, W.H., Thye, F., Kestin, M., Davidson, D.M., Davidson, M.H., Dugan, D.L., Denmark-Wahnefried, W. \& Beling, S. 1992. Oat products and lipid lowering. A meta-analysis. Journal of the American Medical Association 267: 3317-3325.

Robbins, G.S., Pomeranz, Y. \& Briggle, L.W. 1971. Amino acid composition of oat groats. Journal of Agricultural and Food Chemistry 19: 536-539.

Rossander-Hultén, L., Gleerup, A. \& Hallberg, L. 1990. Inhibitory effect of oat products on non-heme iron absorption in man. European Journal of Clinical $\mathrm{Nu}$ trition 44: 788-791.

Saastamoinen, M., Kumpulainen, J. \& Nummela, S. 1989. Genetic and environmental variation of oil content and fatty acid composition of oats. Cereal Chemistry 66: 296-300.

Saha, P.R., Weaver, C.M. \& Mason, A.C. 1994. Mineral availability in rats from intrinsically labelled whole wheat flour of various phytate levels. Journal of Agricultural and Food Chemistry 42: 2531-2535.

Sahasrabudhe, M.R. 1979. Lipid composition of oat (Avena sativa L.). Journal of the American Oil Chemists Society 56: 80-84.

Salmenkallio-Marttila, M., Heiniö, R.-L., Myllymäki, O., Lille, M., Autio, K. \& Poutanen, K. 2004. Relating microstructure, sensory and instrumental texture of processed oat. Agricultural and Food Science 13: 124-137.
Sandberg, A.-S., Larsen, T. \& Sandström, B. 1993. High dietary calcium level decreases colonic phytic degradation in pigs fed a rapeseed diet. Journal of Nutrition 123: 559-566.

Sandström, B., Almgren, A., Kivistö, B. \& Cederblad, Å. 1987. Zinc absorption in humans from meals based on rye, barley and oatmeal, triticale and whole wheat. Journal of Nutrition 177: 1898-1902.

Shamsuddin, A.M. 1995. Inositol phosphates have novel anticancer functions. Journal of Nutrition 125: 725732.

Shutov, A.D. \& Vaintraub, I.A. 1987. Degradation of storage proteins in germinating seeds. Phytochemistry 26: 1557-1566.

Sosulski, F., Krygier, K. \& Hogge, L. 1982. Free, esterified, and insoluble-bound phenolic acids. 3. Composition of phenolic acids in cereal and potato flours. Journal of Agricultural and Food Chemistry 30: 337340.

Sutcliffe, J.F. \& Baset, Q.A. 1973. Control of hydrolysis of reserve materials in the endosperm of germinating oat grains. Plant Science Letters 1: 15-20.

Taylor, D.G., Humphrey, P.M. \& Smith, P.J. 1998. Brewing of English-style ales with malted cereals, other than barley. Master Brewers Association of the Americas, Technical Quarterly 35: 20-23.

Thomson, J.M., Dodd, C.E.R. \& Waites, W.M. 1993. Spoilage of bread by Bacillus. International Biodeterioration and Biodegradation 32: 55-66.

Urquhart, A.A., Altosaar, I. \& Matlashewski, G.J. 1983. Localization of lipase activity in oat grains and milled oat fractions. Cereal Chemistry 60: 181-183.

Urquhart, A.A., Brumell, C.A., Altosaar, G.J., Matlashewski, G.J. \& Sahasrabudhe, M.R. 1984. Lipase activity in oats during grain maturation and germination. Cereal Chemistry 61: 105-108.

von Ceumern, S. \& Hartfield, W. 1984. Activity of lipoxygenase in cereals and possibilities of enzyme inhibition. Fette Seifen Anstrichmittel 86: 204-208.

Weidenbörner, M. \& Kunz, B. 1994. Contamination of different muesli components by fungi. Mycology Research 98: 583-586.

Weidenbörner, M. \& Kunz, B. 1995. Mycoflora of cereal flakes. Journal of Food Protection 58: 809-812.

Welch, R.W. 1977. Fatty acid composition of grain from winter and spring sown oats, barley and wheat. Journal of the Science of Food and Agriculture 26: 269274.

Welch, R.W. 1995. Oats in human nutrition and health. In: Welch, R.W. (ed.). The oat crop. Chapman \& Hall, London. p. 432-479.

White, P.J. \& Armstrong, L.S. 1986. Effect of selected oat sterols on the deterioration of heated soybean oil. Journal of the American Oil Chemists Society 63: 525-529.

Wilhelmson, A., Oksman-Caldentey, K.-M., Laitila, A., Suortti, T., Kaukovirta-Norja, A. \& Poutanen, K. 2001. Development of a germination process for producing high $\beta$-glucan, whole grain food ingredients from oat. Cereal Chemistry 78: 715-720.

Wood, P.J., Weisz, J. \& Fedec, P. 1991. Potential for $\beta$ glucan enrichment in brans derived from oat (Avena 


\title{
AGRICULTURAL AND FOOD SCIENCE
}

\section{Kaukovirta-Norja, A. et al. Germination of oat}

sativa L.) cultivars of different $(1 \rightarrow 3)(1 \rightarrow 4)-\beta$-D-glucan concentrations. Cereal Chemistry 68: 48-51.

$\mathrm{Wu}$, Y.V. 1983. Effect of germination on oats and oat protein. Cereal Chemistry 60: 418-420.

Youngs, V.L. 1986. Oat lipids and lipid-related enzymes. In: Webster, F.H. (ed.). Oats: chemistry and technology. St Paul, Minnesota, American Association of Cereal Chemists. p. 205-226.
Zhang, D., Doehlert, D.C. \& Moore, W.R. 1998. Rheological properties of $(1 \rightarrow 3)(1 \rightarrow 4)-\beta$-D-glucan from raw, roasted, and steamed oat groats. Cereal Chemistry 75: $433-438$.

Zhou, J.R. \& Erdman, J.W. 1995. Phytic acid in health and disease. Critical Reviews in Food Science and Nutrition 35: 495-508.

\section{SELOSTUS}

\section{Idättämällä voi muokata kaurasta uudenlaisia elintarvikeraaka-aineita}

\author{
Anu Kaukovirta-Norja, Annika Wilhelmson ja Kaisa Poutanen \\ VTT Biotekniikka
}

Kaura on terveellinen ja monipuolinen elintarvikeraaka-aine, ja se on tärkeä viljelykasvi suomalaisessa maataloudessa. Kauraa käytetään varsin perinteisesti, ja niinpä kauran menekin ja erityisesti jalostettujen kauratuotteiden viennin lisäämiseksi tarvitaan uudenlaisia prosessointikeinoja ja tuoteideoita. Idätys on vanha keino muokata viljojen siementen koostumusta ja pehmentää niiden rakennetta. Idättämällä on pilkottu huonosti sulavia siementen komponentteja sekä parannettu siementen makua ja ravintoarvoa. Idätyksen tärkein sovellus on ohran mallastaminen oluen raaka-aineeksi. Viime aikaisen terveysvaikutteisten elintarvikekomponentien tutkimuksen myötä on kiinnostuttu myös itäviin siemeniin muo- dostuvista bioaktiivisista yhdisteistä ja itävän siemenen tuottamien entsyymien hyödyntämisestä muokattujen elintarvikeraaka-aineiden valmistuksessa. Bioaktiivisilla yhdisteillä on $\mathrm{mm}$. antioksidatiivisia ja antimikrobisia ominaisuuksia. Hallitulla idätystysprosessilla on mahdollista saada haluttuja yhdisteitä ja ominaisuuksia idätettyihin viljoihin. Tämä kuitenkin edellyttää, että sekä idätysprosessi että itämisen aikaiset biokemialliset tapahtumat tunnetaan hyvin. Kauran idätystä on tutkittu jonkin verran, ja tämä katsaus osoittaa, että idätys on potentiaalinen keino muokata kauraa maistuvien, terveellisten ja laadultaan korkealuokkaisten kaurajalosteiden raaka-aineeksi. 